\title{
Попова В.Б.
}

\section{Анализ структуры валовой продукции сельского хозяйства Тамбовской области}

\author{
ФГБОУ Мичуринский ГАУ
}

(Россия, Мичуринск)

doi: $10.18411 / 1 j-08-2020-88$

idsp: ljournal-08-2020-88

\section{Аннотация}

В статье изучены институциональная и отраслевая структура продукции сельского хозяйства региона; дана оценка существенности структурных различий в динамике и по сравнению со среднерегиональными показателями; произведено сравнение отраслевой структуры аграрного производства в хозяйствах разных категорий.

Ключевые слова: валовая продукция сельского хозяйства, аграрное производство, категории хозяйств, отраслевая структура, структурные сдвиги и различия

\section{Abstract}

The article examines the institutional and sectoral structure of agricultural products in the region; assesses the significance of structural differences in dynamics and in comparison with regional averages; compares the sectoral structure of agricultural production in farms of different categories.

Keywords: gross agricultural output, agricultural production, farm categories, industry structure, structural shifts and differences

Решение задачи увеличения производства сельскохозяйственной продукции отечественными производителями связано с вопросами обеспечения продовольственной безопасности и интегрировано в систему управления стратегическим развитием аграрных регионов страны.

Тамбовская область - субъект Российской Федерации, входящий в состав Центрального федерального округа и Центрально-Черноземного экономического района. Хозяйственная специализация области основана на аграрном производстве, так как климат и черноземные почвы глинистого и тяжелосуглинистого механического состава создают благоприятные условия для сельскохозяйственной деятельности. Большой объем инвестиций, направленный в аграрный сектор за последние годы, также обеспечивает его функционирование как точки роста региональной экономики.

Сельское хозяйство Тамбовской области производит от $2,1 \%$ до 2,5\% валовой сельскохозяйственной продукции страны, занимая по данному показателю в последние годы среди субъектов Российской Федерации 10-12 место (ранжирование произведено в порядке убывания).

Удельный вес Тамбовской области в аграрном производстве Центрального федерального округа составлял в 2016 г. - 8,3\%, в 2017 г. -8,5\%, в 2018 г. - 8,7\%. Среди областей ЦФО Тамбовская область по данному показателю в 2016-2018 гг. занимала 4 место. Удельный вес Тамбовской области в структуре валовой продукции сельского хозяйства Центрально-Черноземного экономического района колеблется от $13,2 \%$ до $16 \%[4$, c.200].

Продукция сельского хозяйства представляет собой сумму объема продукции растениеводства и животноводства всех категорий сельскохозяйственных производителей в стоимостной оценке по фактически действовавшим ценам. 
Институциональная структура характеризует долю продукции сельского хозяйства разных категорий хозяйств в ее общем стоимостном объеме.

Отраслевая структура представляет собой процентное отношение продукции растениеводства и животноводства в стоимости продукции сельского хозяйства.

Как показывают данные таблицы 1, в 2018 г. хозяйствами всех категорий Тамбовской области было произведено продукции сельского хозяйства на сумму 127,3 млрд. руб., в том числе сельскохозяйственными организациями $-91,9$ млрд. руб. (72,2\% от общего объема), хозяйствами населения - 21,3 млрд. руб. (16,8\%), крестьянскими (фермерскими) хозяйствами и индивидуальными предпринимателями (КФХ и ИП) 14,1 млрд. руб. (11,1\%).

Таблица 1.

Продукция сельского хозяйства по категориям хозяйств в Тамбовской области за 2008-2018 г2. (в фактически действовавших иенах; млн. руб.)

\begin{tabular}{|c|c|c|c|c|c|c|c|c|}
\hline \multirow{3}{*}{ Годы } & \multicolumn{6}{|c|}{ Категории хозяйств } & \multirow{2}{*}{\multicolumn{2}{|c|}{$\begin{array}{l}\text { Хозяйства всех } \\
\text { категорий }\end{array}$}} \\
\hline & \multicolumn{2}{|c|}{$\begin{array}{c}\text { сельскохозяйственные } \\
\text { организации }\end{array}$} & \multicolumn{2}{|c|}{ хозяйства населения } & \multicolumn{2}{|c|}{ КФХ и ИП } & & \\
\hline & всего & $\begin{array}{l}\text { в \% к } \\
\text { итогу }\end{array}$ & всего & $\begin{array}{l}\text { в \% к } \\
\text { итогу }\end{array}$ & всего & $\begin{array}{l}\text { в \% к } \\
\text { итогу }\end{array}$ & всего & $\begin{array}{l}\text { в \% к } \\
\text { итогу }\end{array}$ \\
\hline 2008 & 17659,4 & 49,7 & 13432,1 & 37,8 & 4460,9 & 12,5 & 35552,4 & 100 \\
\hline 2009 & 16345,7 & 43,7 & 16657,2 & 44,6 & 4382,0 & 11,7 & 37384,9 & 100 \\
\hline 2010 & 13325,4 & 39,4 & 17061,8 & 50,5 & 3432,0 & 10,1 & 33819,2 & 100 \\
\hline 2011 & 24209,9 & 50,1 & 18215,9 & 37,7 & 5859,8 & 12,1 & 48285,6 & 100 \\
\hline 2012 & 31222,8 & 56,2 & 17745,0 & 32,0 & 6566,3 & 11,8 & 55534,1 & 100 \\
\hline 2013 & 41308,4 & 62,1 & 17950,5 & 27,0 & 7293,6 & 11,0 & 66552,5 & 100 \\
\hline 2014 & 57849,7 & 66,3 & 20488,7 & 23,5 & 8960,3 & 10,3 & 87298,7 & 100 \\
\hline 2015 & 81348,2 & 68,5 & 23054,9 & 19,4 & 14308,4 & 12,1 & 118711,5 & 100 \\
\hline 2016 & 73916,0 & 67,9 & 21893,8 & 20,1 & 13086,4 & 12,0 & 108896,2 & 100 \\
\hline 2017 & 78346,1 & 70,4 & 22130,7 & 19,9 & 10855,0 & 9,8 & 111331,8 & 100 \\
\hline 2018 & 91868,6 & 72,2 & 21339,7 & 16,8 & 14099,7 & 11,1 & 127308,0 & 100 \\
\hline
\end{tabular}

Сравнение структуры валовой продукции сельского хозяйства в 2018 г. со структурой десятилетней и пятилетней давности, выполненное на основе значений индекса Рябцева, показало существенные структурно-динамические сдвиги аграрного производства в области по сравнению с 2008 г. и весьма низкий уровень различий по сравнению с 2014 г.:

$$
\begin{gathered}
I_{R(2008 ; 2018)}=\sqrt{\frac{\sum_{i=1}^{n}\left(d_{i 1}-d_{i 0}\right)^{2}}{\sum_{i=1}^{n}\left(d_{i 1}+d_{i 0}\right)^{2}}}=0,227 ; \\
I_{R(2014 ; 2018)}=\sqrt{\frac{\sum_{i=1}^{n}\left(d_{i 1}-d_{i 0}\right)^{2}}{\sum_{i=1}^{n}\left(d_{i 1}+d_{i 0}\right)^{2}}}=0,062 .
\end{gathered}
$$

Для оценки меры существенности изменения структуры использовалась шкала по критерию индекса Рябцева (табл. 2).

Структурные сдвиги последних десяти лет характеризуются ростом доли сельскохозяйственных организаций, уменьшением доли хозяйств населения и относительно небольшими колебаниями удельного веса фермерского и индивидуального сектора в общем стоимостном объеме сельскохозяйственной продукции региона. 
Таблийа 2.

Шкала оченки меры существенности структурных различий по критерию индекса

Рябиева

\begin{tabular}{|c|c|}
\hline $\begin{array}{c}\text { Интервал значений индекса } \\
\text { Рябцева }\end{array}$ & Характеристика меры структурных различий \\
\hline $0,000-0,030$ & Тождественность структур \\
\hline $0,031-0,070$ & Весьма низкий уровень различий структур \\
\hline $0,071-0,150$ & Низкий уровень структур \\
\hline $0,151-0,300$ & Существенный уровень различий \\
\hline $0,301-0,500$ & Значительный уровень различий \\
\hline $0,501-0,700$ & Весьма значительный уровень различий \\
\hline $0,701-0,900$ & Противоположный тип структур \\
\hline 0,901 и выше & Полная противоположность структур \\
\hline
\end{tabular}

Проведем структурно-территориальный анализ сельскохозяйственного производства по категориям хозяйств Тамбовской области по сравнению с Российской Федерацией, Центральным федеральным округом и Центрально-Черноземный районом за 2016-2018 г. на базе индекса Рябцева.

Данные таблицы 3 показывают существенный уровень различий институциональных структур сельскохозяйственного производства Тамбовской области и РФ, весьма низкий уровень различий структур Тамбовской области и ЦФО, тождественность структур Тамбовской области и ЦЧР.

Таблица 3.

Значения индекса Рябцева для оценки структурно -территориальных различий аграрного производства Тамбовской области за 2016-2018 г2.

\begin{tabular}{|l|c|c|c|}
\hline \multicolumn{1}{|c|}{ База сравнения } & 2016 г. & 2017 г. & 2018 г. \\
\hline РФ & 0,167 & 0,144 & 0,152 \\
\hline ЦФО & 0,071 & 0,025 & 0,032 \\
\hline ЦЧР & 0,063 & 0,020 & 0,026 \\
\hline
\end{tabular}

Из таблицы 4 видно, что в разрезе отраслей сельского хозяйства в 2018 г. в Тамбовской области произведено 70,9 млрд. руб. (55,7\% от общего объема) продукции растениеводства и 56,4 млрд. руб. (44,3\%) продукции животноводства. Это свидетельствует о том, что в сельском хозяйстве области сформировался растениеводческий характер отраслевой структуры производства. В анализируемые годы она значительным образом не изменялась, хотя колебания удельных весов по годам имели место быть.

Существенные изменения претерпела отраслевая структура сельскохозяйственных организаций, где начиная с 2012 г. началось увеличение доли животноводческой продукции. Это связано с началом реализации ряда крупных инвестиционных проектов по свиноводству, развитием мясного птицеводства, строительством молочных комплексов [1,с.266].

Таблица 4.

Объем и отраслевая структура продукиии сельского хозяйства в хозяйствах разных категорий Тамбовской области за 2012 -2018 г2. (в фактически действовавших иченах;

$$
\text { млн. руб.) }
$$

\begin{tabular}{|c|c|c|c|c|c|c|c|}
\hline & 2012 г. & 2013 г. & 2014 г. & 2015 г. & 2016 г. & 2017 г & 2018 г. \\
\hline \multicolumn{8}{|c|}{ Хозяйства всех категорий } \\
\hline $\begin{array}{l}\text { Продукция сельского } \\
\text { хозяйства }\end{array}$ & 55534,1 & 66552,5 & 87298,7 & 118711,5 & 108896,2 & 111331,8 & $\begin{array}{l}127 \\
308,0 \\
\end{array}$ \\
\hline $\begin{array}{l}\text { в том числе } \\
\text {-продукция } \\
\text { растениеводства }\end{array}$ & 34609,9 & 41103,8 & 48491,0 & 75869,8 & 67679,3 & 59670,0 & $\begin{array}{l}70 \\
944,00\end{array}$ \\
\hline в \% к итогу & 62,32 & 61,76 & 55,55 & 63,91 & 62,15 & 53,60 & 55,73 \\
\hline
\end{tabular}




\begin{tabular}{|c|c|c|c|c|c|c|c|}
\hline $\begin{array}{l}\text {-продукция } \\
\text { животноводства }\end{array}$ & 20924,2 & 25448,7 & 38807,7 & 42841,7 & 41216,9 & 51661,8 & 56364,0 \\
\hline в \% к итогу & 37,68 & 38,24 & 44,45 & 36,09 & 37,85 & 46,40 & 44,27 \\
\hline \multicolumn{8}{|c|}{ Сельскохозяйственные организации } \\
\hline $\begin{array}{l}\text { Продукция сельского } \\
\text { хозяйства }\end{array}$ & 31222,8 & 41308,4 & 57849,7 & 81348,2 & 73916,0 & 78346,1 & 91868,6 \\
\hline $\begin{array}{l}\text { в том числе } \\
\text {-продукция } \\
\text { растениеводства }\end{array}$ & 21633,9 & 27123,8 & 31656,8 & 52952,7 & 46569,3 & 39621,7 & 48027,1 \\
\hline в \% к итогу & 69,29 & 65,66 & 54,72 & 65,09 & 63,00 & 50,57 & 52,28 \\
\hline $\begin{array}{l}\text {-продукция } \\
\text { животноводства }\end{array}$ & 9588,9 & 14184,6 & 26192,9 & 28395,5 & 27346,7 & 38724,4 & 43841,5 \\
\hline в \% к итогу & 30,71 & 34,34 & 45,28 & 34,91 & 37,00 & 49,43 & 47,72 \\
\hline \multicolumn{8}{|c|}{ Хозяйства населения } \\
\hline $\begin{array}{l}\text { Продукция сельского } \\
\text { хозяйства }\end{array}$ & 17745,0 & 17950,5 & 20488,7 & 23054,9 & 21893,8 & 22130,7 & 21339,7 \\
\hline $\begin{array}{l}\text { в том числе } \\
\text {-продукция } \\
\text { растениеводства }\end{array}$ & 7248,9 & 7706,0 & 9042,3 & 10253,3 & 9805,8 & 10410,1 & 10025,9 \\
\hline в \% к итогу & 40,85 & 42,93 & 44,13 & 44,47 & 44,79 & 47,04 & 46,98 \\
\hline $\begin{array}{l}\text {-продукция } \\
\text { животноводства }\end{array}$ & 10496,1 & 10244,5 & 11446,4 & 12801,6 & 12088,0 & 11720,6 & 11313,8 \\
\hline в \% к итогу & 59,15 & 57,07 & 55,87 & 55,53 & 55,21 & 52,96 & 53,02 \\
\hline \multicolumn{8}{|c|}{ Крестьянские хозяйства и индивидуальные предприниматели } \\
\hline $\begin{array}{l}\text { Продукция сельского } \\
\text { хозяйства }\end{array}$ & 6566,3 & 7293,6 & 8960,3 & 14308,4 & 13086,4 & 10855,0 & 14099,7 \\
\hline $\begin{array}{l}\text { в том числе } \\
\text {-продукция } \\
\text { растениеводства }\end{array}$ & 5727,1 & 6274,0 & 7791,9 & 12663,8 & 11304,2 & 9638,2 & 12891,0 \\
\hline в \% к итогу & 87,22 & 86,02 & 86,96 & 88,51 & 86,38 & 88,79 & 91,43 \\
\hline $\begin{array}{l}\text {-продукция } \\
\text { животноводства }\end{array}$ & 839,2 & 1019,6 & 1168,4 & 1644,6 & 1782,2 & 1216,8 & 1208,7 \\
\hline в \% к итогу & 12,78 & 13,98 & 13,04 & 11,49 & 13,62 & 11,21 & 8,57 \\
\hline
\end{tabular}

Соотношение растениеводческой и животноводческой продукции в разных категориях хозяйств различно. На сельскохозяйственных организациях оно сложилось примерно на среднеотраслевом уровне. В разных субъектах малого хозяйствования отраслевая структура сельскохозяйственного производства отличается. Производственная деятельность крестьянских (фермерских) хозяйств и индивидуальных предпринимателей имеет выраженную растениеводческая направленность. В хозяйствах населения наблюдается преобладание доли животноводческой продукции [2, с. 145].

В растениеводстве основными производителями зерна, сахарной свеклы и подсолнечника являются сельскохозяйственные организации, картофеля, овощей, фруктов и ягод - хозяйства населения. В животноводстве сельскохозяйственные организации производят большую часть скота и птицы, хозяйства населения - шерсти, яиц и молока. Фермерские хозяйства и индивидуальные предприниматели вносят заметный вклад в производство зерна, семян подсолнечника, молока [3, с.48].

Таким образом, сельское хозяйство региона характеризуется преобладанием производства в сельскохозяйственных организациях, на которые приходится почти 3/4 валовой продукции отрасли, сохранением растениеводческой направленности при динамичном развитии животноводства.

$$
* * *
$$

1. Попова В.Б., Папихина Н.В. Анализ динамики производственной деятельности основных экономикообразующих отраслей Тамбовской области// Актуальные вопросы совершенствования 
бухгалтерского учета и налогообложения организаций: материалы IV Международной научнопрактической конференции. 2015. С.263-273.

2. Попова В.Б., Фецкович. И.В. Анализ сельскохозяйственной деятельности в субъектах малых форм хозяйствования Тамбовской области// Финансовый вестник. 2016. №2 (33). С. 142-151.

3. Попова В.Б., Фецкович И.В. Комплексное исследование аграрного производства с применением статистических методов анализа. Мичуринск: Изд-во Мичуринского ГАУ, 2017. - 112 с.

4. Попова В.Б. Статистические аспекты изучения аграрного производства на региональном уровне//Социально-экономическое развитие России и регионов в цифрах статистики: материалы IV международной научно-практической конференции. 2017. С. 198-220. 